\title{
Erratum to: The interacting effects of temperature, ground disturbance, and herbivory on seedling establishment: implications for treeline advance with climate warming
}

Anne Munier $\cdot$ Luise Hermanutz $\cdot$

John D. Jacobs $\cdot$ Keith Lewis

Published online: 25 February 2014

(C) Springer Science+Business Media Dordrecht 2014

Erratum to: Plant Ecol (2010) 210:19-30

DOI 10.1007/s11258-010-9724-y

The reference "Holtmeier and Broll 2007" has been cited incorrectly in the Introduction and Reference section as "Holtmeier and Moen 2007" in the original publication.

The correct reference should read as:

Holtmeier F.K., Broll, G.B. (2007) Treeline advance: driving processes and adverse factors. Landscape Online 1:1-33

The online version of the original article can be found under doi:10.1007/s11258-010-9724-y.

\footnotetext{
A. Munier $\cdot$ L. Hermanutz $(\bowtie) \cdot$ K. Lewis Department of Biology, Memorial University, Elizabeth St., St. John's, NL A1B 3X9, Canada e-mail: lhermanu@mun.ca

J. D. Jacobs

Department of Geography, Memorial University,

Elizabeth St., St. John's, NL A1B 3X9, Canada
} 